\title{
Genome Sizes in Hepatica Mill: (Ranunculaceae) Show a Loss of DNA, Not a Gain, in Polyploids
}

\author{
B. J. M. Zonneveld \\ Nationaal Herbarium, Leiden University, P.O. Box 9514, 2300 RA Leiden, The Netherlands \\ Correspondence should be addressed to B. J. M. Zonneveld, zonneveld@nhn.leidenuniv.nl
}

Received 8 December 2009; Accepted 25 February 2010

Academic Editor: Johann Greilhuber

Copyright ( 2010 B. J. M. Zonneveld. This is an open access article distributed under the Creative Commons Attribution License, which permits unrestricted use, distribution, and reproduction in any medium, provided the original work is properly cited.

Genome size ( $C$-value) was applied anew to investigate the relationships within the genus Hepatica (Ranunculaceae). More than 50 samples representing all species (except $H$. falconeri), from wild and cultivated material, were investigated. Species of Hepatica turn out to be diploid $(2 n=14)$, tetraploid $(2 n=28)$, and a possible pentaploid. The somatic nuclear DNA contents (2C-value), as measured by flow cytometry with propidium iodide, were shown to range from 33 to $80 \mathrm{pg}$. The Asiatic and American species, often considered subspecies of $H$. nobilis, could be clearly distinguished from European $H$. nobilis. DNA content confirmed the close relationships in the Asiatic species, and these are here considered as subspecies of $H$. asiatica. Parents for the allotetraploid species could be suggested based on their nuclear DNA content. Contrary to the increase in genome size suggested earlier for Hepatica, a significant (6\%-14\%) loss of nuclear DNA in the natural allopolyploids was found.

\section{Introduction}

Phylogenies based on restriction sites of chloroplast and ribosomal DNA and morphological and cytological variations indicate that the genus Hepatica Mill. should be subsumed within genus Anemone (L.) [1]. However there are numerous gaps in the available molecular data [2].Therefore it seems better to refrain from creating new generic or infrageneric taxa in Anemone and keep the classical concept of Hepatica [3]. Hepatica falconeri (Thomson) Steward is sometimes placed in Anemone and sometimes in Hepatica $[1,2]$. However, three of the total eight Hepatica taxa are supposed to be allotetraploids with $H$. falconeri as one of the parents [4]. Therefore it is here attributed to Hepatica. The genus comprises about 12 species disjunctly distributed in the temperate zones of Europe, North America, and East Asia. They can be arranged in two sections: the mainly diploid section Hepatica with $2 n=14$ and the mainly polyploid section Angulosa (Ulbr.) Nakai with $2 n=28$. They are popular as spring-flowering rock garden plants. Almost all species are in cultivation, and enthusiasts especially in Japan grow many cultivars. The boundaries between taxa of various ranks are still a subject of dispute. Weiss-Schneeweiss et al. [4] found incongruent topologies based on nuclear ITS and chloroplast mat $\mathrm{K}$ sequences. Commichau [5] arranged the American and Asiatic species (except H. maxima, Nakai) as varieties under $H$. nobilis Schreb. Dezhi and Robison [6] regarded $H$. yamatutae Nakai as synonymous with $H$. henryi (Oliv.) Steward and $H$. asiatica Nakai to be a variety of $H$. nobilis Schreb. So there is ample scope for further investigation. Although recent studies [7] have substantially clarified systematic relationships within Hepatica, some new problems did arise. The classical taxonomic traits based on morphology and geographical proximity are here supplemented with data on nuclear DNA content. More than 50 different accessions representing all known species except $H$. falconeri (Thomson) Steward, and commonly available hybrids, were measured in an attempt to better understand the infrageneric relationships and to gain insight into the origin of some of the cultivars.

Nuclear DNA content which can conveniently be measured by flow cytometry using propidium iodide (PI), a stoichiometric DNA stain that intercalates in the double helix, is more and more exploited for taxonomic purposes. Where many species in a genus have the same chromosome numbers, differences in nuclear DNA content, when present, 
have proven to be very effective in delimiting infrageneric divisions in a number of taxa [7-18]. Flow cytometry can therefore be considered as a quick and useful method for understanding systematic relationships. Genome sizes are evaluated here in combination with available morphological, geographical, and molecular data. Therefore the here proposed taxonomy is not a single character taxonomy based on genome size alone. Moreover, Greilhuber [19] has clearly shown that intraspecific variation of genome size is much less than assumed. Mabuchi et al. [7] concluded, based on their determination of the nuclear DNA content, that there was an increase in DNA content after tetraploidisation, a not very frequent occurrence $[6,20,21]$. In this study, nuclear DNA content was used anew to test the hypothesized origins of the polyploid taxa and to infer the relationships among the Asian endemic species.

The evolution of genome size ( $C$-value) [17] has received increased attention during recent years. Primitive angiosperms are now supposed to have had small genomes; increases up to a factor 1000 have occurred independently in various modern taxa [22]. Flow cytometry was successfully used to measure the $2 C$-value for several genera [7, 918]. In this paper it is shown, using several accessions for most species, that intraspecific variation is low in Hepatica species. This enabled us to differentiate between intraspecific variation and hybrids and to indicate the parentage of some cultivars.

\section{Materials and Methods}

2.1. Plant Material. Plant material was obtained from the collections of J. Peters, Germany; G. Dunlop (N. Ireland); M. Myers, UK; J. Massey and E. Myrholt, Norway. Where possible, material of known wild origin was used, and care was taken to ensure correct identification of all the material. Vouchers of the species are in the Herbarium of Leiden (L).

2.2. Flow Cytometric Measurement of Nuclear DNA Content. For the isolation of nuclei, about $0.5 \mathrm{~cm}^{2}$ of adult leaf tissue was chopped together with a piece of Agave americana L. "Aureomarginata" as an internal standard. The chopping was done with a new razor blade in a Petri dish in $0.25 \mathrm{ml}$ nucleiisolation buffer to which $0.25 \mathrm{mg} \mathrm{RNase} / \mathrm{ml}$ was added [8]. After adding $1.5 \mathrm{ml}$ propidium iodide (PI) solution $(50 \mathrm{mg}$ $\mathrm{PI} / \mathrm{l}$ in isolation buffer) the suspension with nuclei was filtered through a $30 \mu \mathrm{m}$ nylon filter. The fluorescence of the nuclei for each sample was measured half an hour and one hour after addition of PI, using a Partec CA-II flow cytometer. The optical path contained a HBO mercury lamp, filters KG1, and BG12, dichroic mirror TK500, filter OG570, and a Leitz $50 \times 1$ water immersion objective. Data were analyzed by means of DPAC software (Partec GmbH). The 2C DNA content of the sample was calculated as the sample peak mean, divided by the Agave peak mean, and multiplied with the amount of DNA of the Agave standard. At least three different nuclear isolations were measured twice (= after 30 and 60 minutes) with at least 5000 nuclei for each measurement. Therefore the average data for each accession presented here are based on at least 6 DNA measurements. Most histograms revealed a Coefficient of Variation (CV) of less than $5 \%$. The standard deviation was calculated for the DNA content of each species, using all relevant measurements. Agave americana "Aureomarginata" was chosen as internal standard, because it has a convenient amount of DNA relative to Hepatica. Moreover, it is available yearround, it does not mind several weeks without water, and being a large plant, it can serve numerous determinations, thereby further reducing variation in readings. It also has a low background in PI measurements and shows a single $\mathrm{G}_{0}$ peak, almost lacking $\mathrm{G}_{2}$ arrest. Fresh male human leucocytes $\left(2 \mathrm{C}=7.0 \mathrm{pg} ; 1 \mathrm{pg}\left(=0.978 \times 10^{9}\right.\right.$ base pairs $\left.)[23]\right)$ were chosen as primary standard [24]. This yields $2 \mathrm{C}=15.9 \mathrm{pg}$ for nuclei of Agave americana.

\section{Results}

All known Hepatica species (except $H$. falconeri) were investigated experimentally by flow cytometry. Species are listed with increasing nuclear DNA content (Table 1). A low intraspecific variation is found in most cases. The interspecific variation shows that genome size in diploid Hepatica varies between 33.0 and $36.3 \mathrm{pg}$ (Tables 1 and 3). The difference between the highest and lowest DNA contents is about $3 \mathrm{pg}$, equivalent to nearly $3 \times 10^{9}$ base pairs. The tetraploids vary from 53 to $70 \mathrm{pg}$ and one of the cultivars is likely pentaploid with $79.9 \mathrm{pg}$.

3.1. Section Hepatica (Table 1). (H. americana (DC.) Ker Gawl., H. americana ssp. acuta (Pursh) Zonn., H. asiatica Nakai ssp. asiatica, H. asiatica ssp. japonica (Nakai) Zonn., $H$. asiatica ssp. insularis (Nakai) Zonn., H. asiatica ssp. pubescens (Hiroe) Zonn., H. maxima (Nakai) Nakai, and H. nobilis Schreb.)

Fourteen accessions were measured for $H$. nobilis. They originated from Western and Eastern Europe, from Sweden to Spain. The DNA $C$-values have a rather narrow range of variation. They clearly differ from the American and Asiatic taxa. The value for $H$. nobilis is of average $33.0 \mathrm{pg}$ whereas those for $H$. americana and the Asiatic species are 34.8 and $34.8-36.3 \mathrm{pg}$, respectively. Two taxa are distinguished for North America: H. americana (DC.) Ker Gawl. and $H$. acutiloba DC. (or H. nobilis var. acuta (Pursh) Steyerm). Hepatica americana grows on acid soil and has rounded leaflets whereas $H$. acutiloba has pointed leaflets and grows on limestone. However, they don't differ in nuclear DNA content (Table 1). Moreover both rounded and acute leaflets are found within $H$. nobilis and $H$. japonica. The former taxa are here considered as subspecies: $H$. americana ssp. americana and H. americana ssp. acuta.

Hepatica asiatica ssp. japonica is often considered as a variety or subspecies of $H$. nobilis. However, its genome size is more in line with the other Asiatic species. The Japanese $H$. asiatica ssp. pubescens is confirmed to be tetraploid. Its genome size is in line with it being an autotetraploid of $H$. asiatica ssp. japonica. H. maxima is restricted to the Ullung 
TABLE 1: Hepatica species with their nuclear DNA content in pg, average for the species, standard deviation, and origin.

\begin{tabular}{|c|c|c|c|c|}
\hline Hepatica species & $\begin{array}{c}\text { 2C DNA } \\
\text { in pg }\end{array}$ & Average & $\begin{array}{l}\text { Standard } \\
\text { deviation }\end{array}$ & $\begin{array}{l}\text { Origin } \\
\text { (as = received as) }\end{array}$ \\
\hline \multicolumn{5}{|l|}{ Section Hepatica } \\
\hline H. nobilis Schreber & 32.7 & 33.0 & 0.9 & Sweden \\
\hline H. nobilis Schreber & 32.7 & & & Poland \\
\hline H. nobilis Schreber & 33.2 & & & hort. blue flower \\
\hline H. nobilis Schreber & 32.3 & & & hort. pink flower \\
\hline H. nobilis Schreber & 32.9 & & & hort. white flower \\
\hline H. nobilis Schreber & 32.7 & & & hort. Rubra plena \\
\hline H. nobilis Schreber & 33.7 & & & Sweden, forma Plena \\
\hline H. nobilis Schreber & 33.3 & & & "Crenatiloba" \\
\hline H. nobilis Schreber & 33.9 & & & Marmor Crenata' \\
\hline H. nobilis Schreber & 33.3 & & & Walter Otto' (double) \\
\hline H. nobilis Schreber & 33.2 & & & as var glabrata, Sweden \\
\hline H. nobilis Schreber & 33.2 & & & as var glabrata, S.Oeland \\
\hline H. nobilis Schreber & 32.3 & & & as var pyrenaica \\
\hline H. americana ssp. acuta (Pursh) Zonn. & 34.6 & 34.8 & 1.0 & USA, on limestone \\
\hline H. americana ssp. americana (DC.) Ker Gawl. & 34.9 & & & USA, on acid soil \\
\hline H. maxima (Nakai) Nakai & 35.9 & 34.8 & 2.2 & Korea, BSWJ 4344 \\
\hline H. maxima (Nakai) Nakai & 34.0 & & & Korea \\
\hline H. maxima (Nakai) Nakai & 34.4 & & & Korea, Ullung Do \\
\hline H. asiatica Nakai ssp. asiatica & 36.6 & 36.3 & 1.4 & China \\
\hline H. asiatica Nakai ssp. asiatica & 35.9 & & & Korea \\
\hline H. asiatica ssp. insularis (Nakai) Zonn. & 34.7 & 35.4 & 1.5 & Korea, BSWJ 859 \\
\hline H. asiatica ssp. insularis (Nakai) Zonn. & 36.1 & & & Korea, Cheju Do \\
\hline H. asiatica ssp. japonica (Nakai) Zonn. & 35.6 & 35.8 & 0.6 & Japan, blue flower \\
\hline H. asiatica ssp. japonica (Nakai) Zonn. & 36.4 & & & Japan, pink flower \\
\hline H. asiatica ssp. japonica (Nakai) Zonn. & 35.4 & & & Japan \\
\hline H. asiatica ssp. pubescens (Hiroe) Zonn. & 70.0 & 70.0 & 2.9 & Japan \\
\hline H. asiatica ssp. pubescens (Hiroe) Zonn. & 79.9 & 79.9 & 0.4 & Japan, "Tenjinbai” \\
\hline \multicolumn{5}{|l|}{ Section Angulosa (Ulbr.) Nakai } \\
\hline H. falconeri (Thomson) Steward & $25.9 *$ & & & Kashmir, Pakistan \\
\hline H. henryi Steward & 53.2 & 53.0 & 2.9 & China \\
\hline H. henryi Steward & 52.7 & & & via E. Myrholt \\
\hline H. transsilvanica Fuss & 55.5 & 54.2 & 2.5 & Lilacina' \\
\hline H. transsilvanica Fuss & 54.4 & & & Bulgaria \\
\hline H. transsilvanica Fuss & 54.2 & & & Elison Spence' \\
\hline H. transsilvanica Fuss & 54.2 & & & Loddon Blue' \\
\hline H. transsilvanica Fuss & 52.9 & & & \\
\hline H. yamatutae Nakai & 58.2 & 58.3 & 2.1 & China, Emei Shan \\
\hline H. yamatutae Nakai & 59.5 & & & China, "Marmorata" \\
\hline H. yamatutae Nakai & 58.9 & & & China, black leaf \\
\hline H. yamatutae Nakai & 56.4 & & & China, Emei Shan \\
\hline
\end{tabular}

${ }^{*}$ Recalculated from [7] 
island off the Korean coast. It grows in a humid, largely frostfree environment. So it comes as no surprise that it is by far the largest plant in leaf and flower of this genus. It is also set apart in ITS and matK trees and isozyme profile from the other Asiatic species. So it might have diverged stronger, but this is not reflected in its similar genome size. The diploid Asiatic species that have a similar genome size are often considered as varieties of $H$. nobilis. They are closely related and are here transferred to subspecies status under $H$. asiatica as ssp. asiatica, ssp. insularis, ssp. japonica, and ssp. pubescens.

3.2. Section Angulosa (Ulbr.) Nakai (Table 1). (H. falconeri (Thomson) Steward, H. henryi (Oliv.) Steward, H. transilvatica Fuss, and H. yamatutai Nakai)

Hepatica falconeri has by far the lowest amount of DNA of any Hepatica species. If its genome size is recalculated from Mabuchi et al. [7] with Hordeum vulgare "Sultan" = $10 \mathrm{pg}$ instead of 11.12 (see discussion) and brought in line with other results here presented, it has $25.9 \mathrm{pg}$. This might indicate an early split-off from the genus, but there is no further evidence to substantiate this. The diploid $H$. falconeri seems to be one of the parents of the three allotetraploids. This is based on the strongly crenate leaves of both $H$. falconeri and the tetraploids, their geographical proximity and the additive DNA $C$-values from $H$. asiatica and $H$. falconeri.

$H$. henryi with $53.0 \mathrm{pg}$ has been attributed to the parents $H$. falconeri $\times H$. asiatica [4]. This would result in a plant with $(25.9+36.3)=62.2 \mathrm{pg})$. This value is higher than the value found here indicating a loss of $14.8 \%$ of DNA in this allotetraploid. A similar loss is found for $H$. transsilvanica with $54.2 \mathrm{pg}$ suggested to be an allotetraploid of $H$. falconeri $\times H$. nobilis. That would result in a plant with $(25.9+33.0)=58.9 \mathrm{pg}$, an $8 \%$ loss. H. yamatutae comes from the same areas as $H$. henryi but has 58.3 pg nuclear DNA, 5.3 pg more, supporting the conclusion that these taxa are distinct and worthy of recognition. H. yamatutae with $58.3 \mathrm{pg}$ comes closer to a possible cross of $H$. falconeri $\times$ $H$. asiatica $(61.7 \mathrm{pg})$. Its low loss of nuclear DNA suggests a more recent origin. However $H$. yamatutae and $H$. henryi might have undergone different genome reshapings after polyploid forming, depending on a combination of genetic and ecological factors.

3.3. Comparing Natural and Artificial Hybrids (Table 2). Nuclear DNA value in Hepatica can also be of use in determining the origin of artificial hybrids. Many of the numerous Hepatica cultivars are of hybrid origin and the parentage is known in most cases. For this study 13 cultivars of garden origin were investigated. When the putative hybridisation is between species with distinct DNA $C$-values, the expected intermediate DNA value of putative hybrids is readily apparent.

The genome sizes for the diploid artificial hybrids $H$. americana $\times H$. nobilis and $H$. maxima $\times H$. nobilis show a small loss of $3.5 \%$ compared to the average of their parents (Table 2). A low loss of $2.5 \%$ is also found for the tetraploid, artificial hybrids $H$. transsilvanica $\times H$. asiatica ssp. pubescens and $H$. transsilvanica $\times H$. yamatutae. Peculiar is the fact that for the triploid artificial hybrids $H$. nobilis $\times H$. transsilvanica $(H . \times$ media Simonk.) and $H$. japonica $\times H$. transsilvanica a gain of $3.2 \%$ is found.

Interesting is $H$. asiatica ssp. pubescens "Tenjinbai" with $79.9 \mathrm{pg}$ whereas the tetraploid form from Japan $H$. asiatica ssp. pubescens has a genome size of only $70 \mathrm{pg}$.

\section{Discussion}

For two taxa, H. americana ssp. acuta $(33.1 \mathrm{pg})$ and $H$. americana ssp. americana (33.2 pg), genome size was determined already by Feulgen densitometry more than 40 years ago [25]. These values are comparable with the present values of 34.9 and $34.6 \mathrm{pg}$. Nuclear DNA content for all species of Hepatica was determined recently by Mabuchi et al. [7]. However, they only present in their table (Table 3 ) the relative fluorescence compared with Hordeum vulgare with 11.12 pg. Doležel et al. [26] have shown, based on the combined results of four laboratories, that the $2 \mathrm{C}$-value of $H$. vulgare is close to $10.0 \mathrm{pg}$ of DNA. Moreover, in the Kew list of DNA $C$-values there are 17 values for Hordeum vulgare. The average value is $10.2 \mathrm{pg}$, close to the value of Doležel et al. It seems inappropriate that instead of this average value the second highest value with $11.12 \mathrm{pg}$ was chosen as "prime value". The results of Mabuchi et al. [7] are recalculated with the value of $10.0 \mathrm{pg}$ and expressed as a $2 \mathrm{C}$-value in pg (Table 3 ). This resulted in still somewhat higher values for the diploids. Moreover, the DNA $C$-value for $H$. falconeri was adjusted further to bring it in line with the present values. Contrary to the similar results for the diploids, the two polyploids erroneously supposed to be derived from a doubling of $H$. falconeri are about 9\% higher than expected [7]. This can be partly explained as done by Weiss-Schneeweiss et al., [4] by assuming other parents. Even then their values for the tetraploids seem (9\%$15 \%)$ too high, compared with our results. This deviation in their values for the tetraploids is also demonstrated in their value of 89.2 for $H$. nobilis var. pubescens (M.Hiroe) Kitamura (here $H$. asiatica ssp. pubescens). This is $6.9 \%$ higher than the doubled value for their $H$. nobilis var. japonica Nakai (41.7 pg). They therefore suggest that the tetraploids have gained DNA compared with their putative diploid parents. This would imply a deviation from the general trend in angiosperms of genome size reduction after polyploidization [21, 27]. It cannot be excluded that the linearity of their apparatus was not appropriate [7]. Repetitive DNA elements, including retrotransposons, are major components of eukaryotic genomes and such elements have a tendency towards amplification [24]. Major decreases in genome size occur less frequently and such decreases have been observed following a doubling of the total genome by polyploidization $[6,20]$ or the change from perennial to annual habit [20]. The genome sizes presented here indicate (Table 1) that there actually is a slightly lower genome size of $H$. asiatica ssp. pubescens (70.0 pg) compared with the double value of its parent $H$. asiatica ssp.japonica (Nakai) Zonn.(35.8 pg). Natural allotetraploids seem to have lost 
TABLe 2: Natural and artificial hybrids of Hepatica Mill. with their nuclear DNA content in pg, standard deviation calculated amount of nuclear DNA (see text), \% DNA loss, ploidy, and cultivar name.

\begin{tabular}{|c|c|c|c|c|c|c|}
\hline Hepatica hybrids & $\begin{array}{c}\text { 2C DNA } \\
\text { in pg } \\
\text { measured }\end{array}$ & St. dev. & $\begin{array}{l}\text { 2C DNA } \\
\text { in pg } \\
\text { Calculate }\end{array}$ & $\begin{array}{l}\text { \% DNA loss } \\
\text { or gain } \\
\text { from parents }\end{array}$ & $\begin{array}{l}\text { Ploidy } \\
\text { based on } \\
2 C \text {-value }\end{array}$ & Cultivar name \\
\hline H. americana ssp. acuta $\times$ H. nobilis & 32.5 & 0.5 & 33.9 & -3.5 & $2 \times$ & Schlyter' \\
\hline H. maxima $x H$. nobilis & 32.5 & 0.1 & 33.9 & -3.5 & $2 \times$ & Frances' \\
\hline H. nobilis $\times$ transsilvanica $(\times$ media Simonk. $)$ & 43.7 & 1.3 & 43.2 & 2.6 & $3 \times$ & Ballardii’ \\
\hline H. nobilis $\times H$. transsilvanica $(H . \times$ media Si'monk. $)$ & 44.1 & & 43.2 & & $3 \times$ & Buis' \\
\hline H. nobilis $\times$ transsilvanica $(H . \times$ media Simonk. $)$ & 45.2 & & 43.2 & & $3 \times$ & Marmorata' \\
\hline H. americana $\times H$. transsilvanica & 44.2 & 1.9 & 44.4 & -0.5 & $3 \times$ & Millstream Merlin’ \\
\hline H. asiatica ssp. japonica $\times H$. transsilvanica & 47.1 & 0.4 & 45.0 & 4.7 & $3 \times$ & Prof. F. Hildebrand' \\
\hline H. transsilvanica $\times H$. pubescens (as "Tenjinbai") & 59.9 & 1.6 & 62.1 & -3.1 & $4 \times$ & Röttgersbüttler Röschen' \\
\hline H. transsilvanica $\times H$. pubescens (as “Tenjinbai") & 59.0 & & 62.1 & & $4 \times$ & Weinreichs Weisse' \\
\hline H. transsilvanica $\times H$. pubescens & 61.7 & & 62.1 & & $4 \times$ & Prof. F. Hildebrand' \\
\hline H. transsilvanica $\times$ H. yamatutae & 54.8 & 2.0 & 56.2 & -2.5 & $4 \times$ & Harvington Beauty' \\
\hline H. transsilvanica $\times$ H. yamatutae & 55.1 & 1.9 & 56.2 & -2.0 & $4 \times$ & NT4' \\
\hline H. transsilvanica Fuss & 54.2 & 2.5 & $* 58.9$ & -8.0 & $4 \times$ & data from Table 1 \\
\hline H. henryi (Oliv.) Steward & 53.0 & 2.9 & $* * 62.2$ & -14.8 & $4 \times$ & data from Table 1 \\
\hline H. yamatutae Nakai & 58.3 & 2.1 & $* * 62.2$ & -6.3 & $4 \times$ & data from Table 1 \\
\hline H. asiatica ssp. pubescens & 70.0 & 2.9 & 71.6 & -2.3 & $4 \times$ & data from Table 1 \\
\hline H. asiatica ssp. pubescens "Tenjinbai" & 79.9 & 0.4 & 89.5 & -10.7 & $5 \times$ & data from Table 1 \\
\hline
\end{tabular}

${ }^{*}$ calculated with $H$. falconeri $\times H$. nobilis as parents. ${ }^{* *}$ calculated with $H$. falconeri $\times H$. asiatica as parents.

$8 \%-15 \%$ of their genome as it happens often with old tetraploids [21, 27], whereas the autotetraploid $H$. asiatica ssp. pubescens shows only a $2.3 \%$ loss. It has already been observed [4] that half of the four 5S RNA and 35S RNA sites is gradually lost in some populations of the tetraploids. It cannot be excluded that an extinct/not yet discovered relative of $H$. falconeri or $H$. asiatica with a lower amount of nuclear DNA was involved. Similar large decreases in genome size for tetraploids compared with their diploid parents were earlier reported for the tetraploid Ranunculus acris (13\%) [18] and Ranunculus ficaria (24\%) [28]. One wonders whether or not these losses of nuclear DNA $(6.3 \%, 8 \%$, and $14.8 \%)$ found here in the allotetraploids of Hepatica are indicative for the age of these tetraploids.

Interesting is $H$. asiatica ssp. pubescens "Tenjinbai" having with $79.9 \mathrm{pg}$ the highest nuclear DNA content measured here for Hepatica. The tetraploid form from Japan $H$. asiatica ssp. pubescens, has a genome size of only $70 \mathrm{pg}$. If $H$. "Tenjinbai" is a pentaploid form of H. asiatica ssp. pubescens it would have lost $9 \%$ of its DNA and if it was a hexaploid form, it would have lost $24 \%$ of its DNA. The pentaploidy seems to be the most likely explanation, although hexaploidy cannot be excluded seeing the similar high DNA loss of $24 \%$ reported for the tetraploid Ranunculus ficaria [28]. Hiroe [29] reported on a hexaploid var. pubescens from Mountain Fujiwara. Hepatica "Tenjinbai" might be such a plant. However, Hara and Kurosawa [30] did find only tetraploid plants at this locality. It suggests that further molecular and cytological work is required to ascertain the true genetic make-up of this taxon. The artificial hybrids supposed to be between $H$. transsilvanica and $H$. asiatica ssp. pubescens "Tenjinbai" should result in plants with $(79.9+$ $54.2) / 2=67 \mathrm{pg}$. However, a value of $60.2 \mathrm{pg}$ is found for three different cultivars (Table 2), suggesting a DNA loss of $10 \%$. More likely the second parent in this cross was just plain $H$. asiatica ssp. pubescens instead of $H$. "Tenjinbai" resulting in a calculated value of $62.1 \mathrm{pg}$ for the hybrid and an actual DNA loss of $3.1 \%$. This is in line with the loss in the other artificial tetraploid hybrids. The losses in the artificial tetraploids are thus lower than the losses in the natural tetraploids $H$. henryi, $H$. transsilvanica, and H. yamatutae where we find losses of nuclear DNA compared with their supposed parents of $8 \%$, $14.8 \%$, and $6.3 \%$, respectively. This indicates that there is over time a slow but increasing loss of DNA in these natural allotetraploids that are of older age than the artificial hybrids mentioned above.

Weiss-Scheeweiss et al. [4] investigated the phylogenetic relationships of Hepatica. This was inferred from the maximum likelihood of the nuclear internal transcribed spacer ITS and the plastid matK region, and also on karyotype morphology, banding patterns and rDNA localization. Nuclear and plastid sequences resulted in incongruent topologies mainly because of the position of some tetraploid taxa. Our results seem incongruent with both topologies obtained.

\section{Evolutionary Considerations}

Based on not only genome size but also leaf shapes, flower color, and geographical arguments, the following reasoning seems plausible. Hepatica falconeri is the basal species with only $25.9 \mathrm{pg}$ of DNA [7] and could be a relict, surviving in Pakistan. There could have been a spread eastwards 
TABLE 3: Genome sizes of Hepatica compared with results of Mabuchi et al. [7] and idem recalculated.

\begin{tabular}{lcccc}
\hline & This article & $\begin{array}{c}\text { Mabuchi et al. [7] } \\
\text { H. vulgare =11.12 pg }\end{array}$ & $\begin{array}{c}\text { recalculated } \\
\text { H. vulgare = 10.0 pg }\end{array}$ & $\begin{array}{c}\text { \% difference } \\
\text { between column B and D }\end{array}$ \\
\hline H. falconeri (Thomson) Steward & $25.9^{*}$ & 30.2 & 27.2 & $\mathbf{4 . 2}$ \\
\hline H. nobilis Schreber & 33.0 & 38.3 & 34.4 & $\mathbf{4 . 6}$ \\
H. americana (DC.) Ker Gawler & 34.6 & 40.3 & 36.2 & $\mathbf{3 . 7}$ \\
H. americana ssp. acuta (Pursh) Zonn. & 34.9 & 40.3 & 37.5 & $\mathbf{7 . 8}$ \\
H. maxima (Nakai) Nakai & 34.8 & 41.7 & 37.5 & $\mathbf{5 . 9}$ \\
H. asiatica ssp. insularis (Nakai) Zonn. & 35.4 & 41.7 & 38 & $\mathbf{4 . 7}$ \\
H. asiatica Nakai ssp. asiatica & 36.3 & 42.3 & 37.5 & $\mathbf{4 . 7}$ \\
H. asiatica ssp. japonica (Nakai) Zonn. & 35.8 & 41.7 & 59.2 & $\mathbf{1 1 . 7}$ \\
\hline H. henryi (Oliv.)Steward & 53.0 & 65.8 & 69.8 & $\mathbf{1 0 . 3}$ \\
H. transsilvanica Fuss & 54.2 & 66.5 & $\mathbf{6 3 . 8}$ & $\mathbf{9 . 4}$ \\
H. yamatutae Nakai & 58.3 & 70.9 & 80.2 & $\mathbf{1 4 . 6}$ \\
H. asiatica ssp. pubescens (Hiroe) Zonn. & 70.0 & 89.2 & & \\
\hline
\end{tabular}

* calculated from [7]

to Eastern Asia (H. asiatica, H. maxima, H. asiatica ssp. insularis, and $H$. asiatica ssp. japonica) westwards to Europe ( $H$. nobilis), and via the bridges in the Miocene to eastern North America [31], in all cases with an increase in genome size. Apart from $H$. asiatica ssp. pubescens the other three tetraploids seem to be of allotetraploid origin with a crenateleaved species like $H$. falconeri or of a related, unknown taxon as one parent. Hepatica yamatutae is endemic to the Emei Shan, Sichuan. This is inside the territory of the more widespread H. henryi (China: Hubei, Hunan, Shaanxi, Sichuan [7]). For H. yamatutae there is only a $6 \%$ loss of nuclear DNA, whereas a 12\% loss was calculated for $H$. henryi from the same area. Maybe this and its small territory point to a more recent origin of $H$. yamatutae compared with $H$. henryi that is supposed to have the same parents.

\section{Conclusions}

Flow cytometry can be a useful tool to indicate the relationship and taxonomic status of Hepatica accessions. Although the DNA content is not unique to every taxon, many species (and some subspecies) can be identified using this method.

Taxa clearly different in nuclear DNA amount are considered good species. This does not mean that taxa with identical DNA amount, must always be considered as constituting a single species. The nuclear DNA amounts should always be evaluated in combination with morphological/molecular data, just as any other taxonomic characters. In some cases, the measured DNA value gives rise to questions about the perceived taxonomic relationship of certain taxa. The speed and cost effectiveness of measuring nuclear DNA content and its predicative accuracy makes it useful as a tool for identifying the origin of Hepatica taxa.

\section{New Name Combinations}

The above results have demonstrated that the Asiatic hepaticas are different in nuclear DNA content from $H$. nobilis.
Therefore four diploid Asiatic taxa are arranged under $H$. asiatica as they are very similar in DNA $2 C$-value. They are also geographically connected and isolated from $H$. nobilis. The two American taxa, differing mainly in leaf shape and ecology, have similar genome sizes that differ from that of $H$. nobilis. They are better considered as subspecies from $H$. americana.

- H. americana ssp. acuta (Pursh) Zonn stat. nov. Basionym H. triloba Chaix var. acuta Pursh [32].

- H. asiatica ssp. insularis (Nakai) Zonn. stat. nov. Basionym: H. insularis Nakai [33].

- H. asiatica ssp. japonica (Nakai) Zonn. stat. nov. Basionym: H. nobilis var. japonica Nakai [34].

- H. asiatica ssp. pubescens (M.Hiroe) Zonn. Basionym: Anemone hepatica var. pubescens M. Hiroe [29] and Kadota [35].

\section{Acknowledgments}

Dr. J. F. Veldkamp (L) is thanked for critically examining the manuscript. The contribution of plants by the donors listed above is gratefully acknowledged.

\section{References}

[1] S. B. Hoot, A. A. Reznicek, and J. D. Palmer, "Phylogenetic relationships in Anemone (Ranunculaceae) based on morphology and chloroplast DNA," Systematic Botany, vol. 19, no. 1, pp. 169-200, 1994.

[2] F Ehrendorfer and R. Samuel, "Contributions to a molecular phylogeny and systematics of Anemone and related genera (Ranunculaceae-Anemoninae)," Acta Phytotax. Sinica, vol. 39, pp. 293-307, 2001.

[3] M. Takamura, "Hepatica," in Die naturlichen Pflanzenfamilien, P. Hiepko, Ed., pp. 349-351, Duncker \& Humbolt, Berlin, Germany, 2nd edition, 1995.

[4] H. Weiss-Schneeweiss, G. M. Schneeweiss, T. F. Stuessy, et al., "Chromosomal stasis in diploids contrasts with genome restructuring in auto- and allopolyploid taxa of Hepatica 
(Ranunculaceae)," New Phytologist, vol. 174, no. 3, pp. 669682, 2007.

[5] M. A. Commichau, Hepatica: Aktuelle Uberblick uber die Gattung, Autodidaktische Herausgabe, 2005.

[6] F. Dezhi and O. B. Robinson, "Hepatica," in Flora of China, vol. 6, p. 328, Science Press, Beijing, China, 2000.

[7] T. Mabuchi, H. Kokubun, M. Mii, and T. Ando, "Nuclear DNA content in the genus Hepatica (Ranunculaceae)," Journal of Plant Research, vol. 118, no. 1, pp. 37-41, 2005.

[8] D. Ohri, "Genome size variation and plant systematics," Annals of Botany, vol. 82, supplement A, pp. 75-83, 1998.

[9] B. J. M. Zonneveld and F. Van Iren, "Genome size and pollen viability as taxonomic criteria: application to the genus Hosta," Plant Biology, vol. 3, no. 2, pp. 176-185, 2001.

[10] B. J. M. Zonneveld, "Nuclear DNA contents of all species of Helleborus (Ranunculaceae) discriminate between species and sectional divisions," Plant Systematics and Evolution, vol. 229, no. 1-2, pp. 125-130, 2001.

[11] B. J. M. Zonneveld, J. M. Grimshaw, and A. P. Davis, "The systematic value of nuclear DNA content in Galanthus," Plant Systematics and Evolution, vol. 241, no. 1-2, pp. 89-102, 2003.

[12] B. J. M. Zonneveld and G. D. Duncan, "Taxonomic implications of genome size and pollen colour and vitality for species of Agapanthus L'Héritier (Agapanthaceae)," Plant Systematics and Evolution, vol. 241, no. 1-2, pp. 115-123, 2003.

[13] B. J. M. Zonneveld and E. J. Van Jaarsveld, "Taxonomic implications of genome size for all species of the genus Gasteria Duval (Aloaceae)," Plant Systematics and Evolution, vol. 251, no. 2-4, pp. 217-227, 2005.

[14] B. J. M. Zonneveld and G. D. Duncan, "Genome size for the species of Nerine Herb. (Amaryllidaceae) and its evident correlation with growth cycle, leaf width and other morphological characters," Plant Systematics and Evolution, vol. 257, no. 3-4, pp. 251-260, 2006.

[15] B. J. M. Zonneveld, "The systematic value of nuclear DNA content for all species of Narcissus L. (Amaryllidaceae)," Plant Systematics and Evolution, vol. 275, no. 1-2, pp. 109-132, 2008.

[16] B. J. M. Zonneveld, "The systematic value of nuclear genome size for "all" species of Tulipa L. (Liliaceae)," Plant Systematics and Evolution, vol. 281, no. 1-2, pp. 217-245, 2009.

[17] J. Greilhuber, "Evolutionary changes of DNA and Heterochromatin amounts in the Scilla bifolia Group (Liliaceae)," Plant Systematics and Evolution, supplement 2, pp. 263-280, 1979.

[18] D. Goepfert, "Karyotypes and DNA content in species of Ranunculus L. and related genera," Botaniska Notiser, vol. 127, pp. 464-489, 1974.

[19] J. Greilhuber, "Intraspecific variation in genome size: a critical reassessment," Annals of Botany, vol. 82, supplement A, pp. 2735, 1998.

[20] M. D. Bennett, "Nuclear DNA content and minimum generation time in herbaceous plants.," Proceedings of the Royal Society of London. Series B, vol. 181, no. 63, pp. 109-135, 1972.

[21] I. J. Leitch and M. D. Bennett, "Genome downsizing in polyploid plants," Biological Journal of the Linnean Society, vol. 82, no. 4, pp. 651-663, 2004.

[22] I. J. Leitch, M. W. Chase, and M. D. Bennett, "Phylogenetic analysis of DNA C-values provides evidence for a small ancestral genome size in flowering plants," Annals of Botany, vol. 82, supplement A, pp. 85-94, 1998.

[23] T. R. Tiersch, R. W. Chandler, S. S. Wachtel, and S. Elias, "Reference standards for flow cytometry and application in comparative studies of nuclear DNA content," Cytometry, vol. 10, no. 6, pp. 706-710, 1989.
[24] J. L. Bennetzen and E. A. Kellog, "Do plants have a one way ticket to genomic obesity?" The Plant Cell, vol. 9, pp. 15091514, 1997.

[25] K. Rothfels, E. Sexsmith, M. Heimburger, and M. O. Krause, "Chromosome size and DNA content of species of Anemone L. and related genera (Ranunculaceae)," Chromosoma, vol. 20, no. 1, pp. 54-74, 1966.

[26] J. Doležel, J. Greilhuber, S. Lucretti, et al., "Plant genome size estimation by flow cytometry: inter-laboratory comparison," Annals of Botany, vol. 82, supplement A, pp. 17-26, 1998.

[27] E. A. Kellogg and J. L. Bennetzen, "The evolution of nuclear genome structure in seed plants," American Journal of Botany, vol. 91, no. 10, pp. 1709-1725, 2004.

[28] J. B. Smith and M. D. Bennett, "DNA variation in the genus Ranunculus," Heridity, vol. 35, pp. 231-239, 1975.

[29] M. Hiroe, "A cytotaxonomical study on Anemone hepatica L. (Ranunculaceae) of Japan," The Botanical Magazine Tokyo, vol. 70, 7 pages, 1957.

[30] H. Hara and S. Kurosawa, "Differentiation within Anemone hepatica L. of Japan,” The Journal of Japanese Botany, vol. 33, pp. 265-275, 1958.

[31] J. Wen, "Evolution of eastern asian and eastern North American disjunct distributions in flowering plants," Annual Review of Ecology and Systematics, vol. 30, pp. 421-455, 1999.

[32] F. T. Pursh, in Flora Americae Septentrionalis, vol. 2, p. 391, White, Cochrane \& Co., London, UK, 1814.

[33] T. Nakai, "Japanese Hepatica," The Journal of Japanese Botany, vol. 13, p. 309, 1937.

[34] T. Nakai, "Japanese Hepatica," The Journal of Japanese Botany, vol. 13, p. 308, 1937.

[35] Y. Kadota, in Flora of Japan Angiospermae-Dicotyledonae: Archichlamydiae, vol. 2a of K. Iwatsuki, D. E. Bouford and $H$. Ohba, Eds., p. 297, Kodansha, Tokyo, Japan, 2006. 

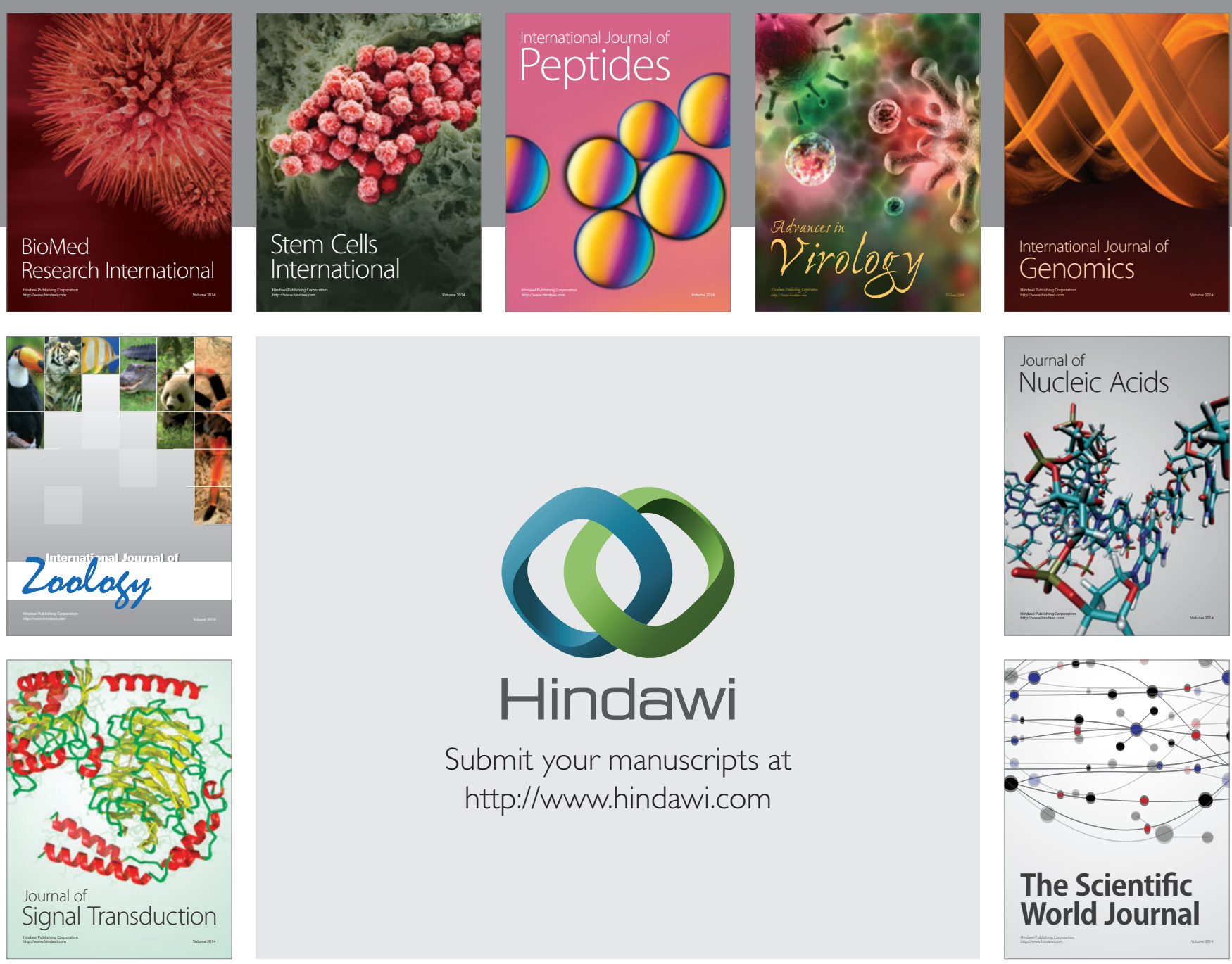

Submit your manuscripts at

http://www.hindawi.com
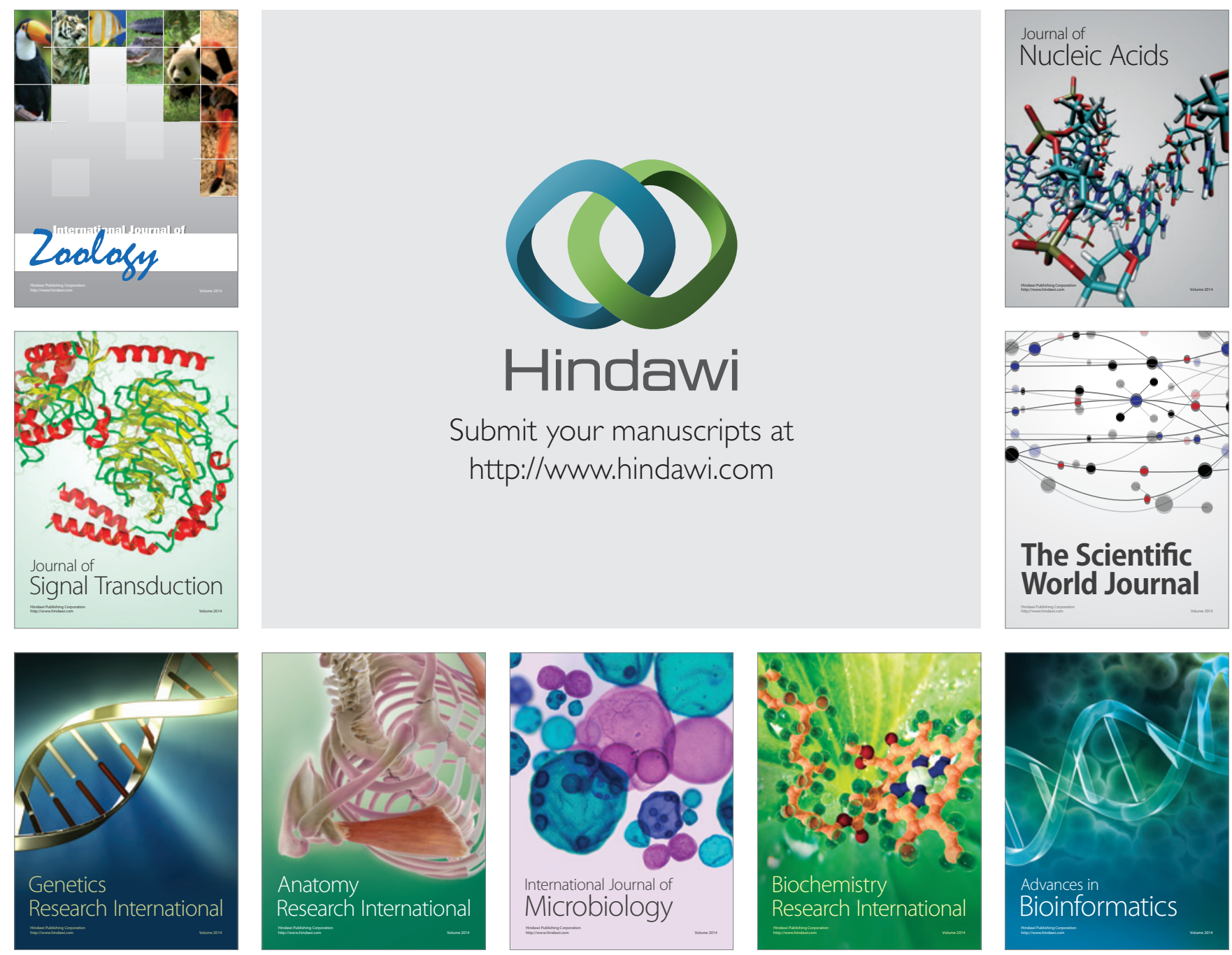

The Scientific World Journal
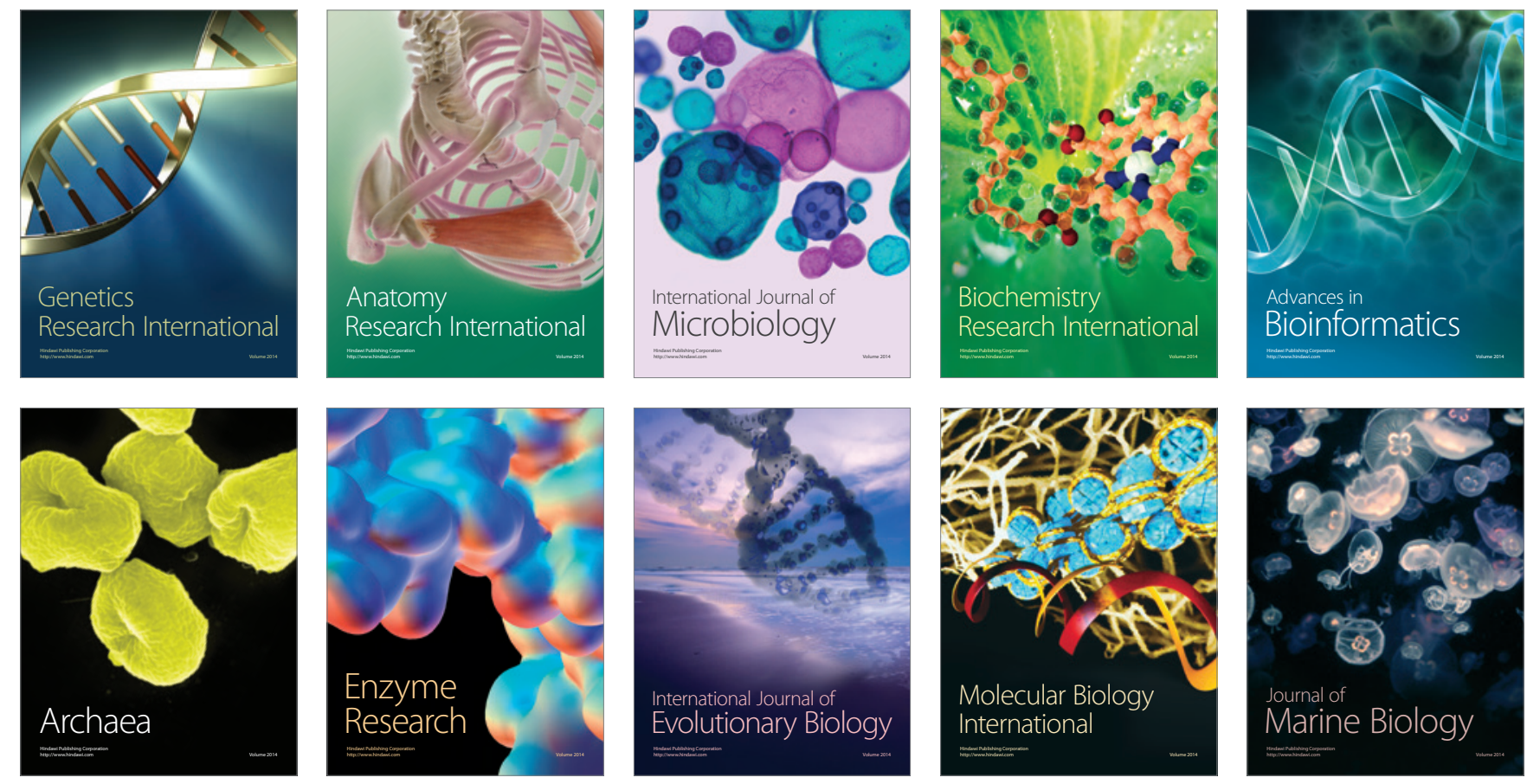